\title{
Hematological and biochemical reference intervals for adult Croatian Posavac horse
}

\author{
Darko Grden, Jelena Gotić, Karol Šimonji, Nada Kučer*, Vladimir Mrljak, \\ Iva Šmit, Martina Crnogaj, and Vesna Matijatko
}

Clinic for Internal Diseases, Faculty of Veterinary Medicine, University of Zagreb, Zagreb, Croatia

\section{GRDEN, D., J. GOTIĆ, K. ŠIMONJI, N. KUČER, V. MRLJAK, I. ŠMIT, M. CRNOGAJ, V. MATIJATKO: Hematological and biochemical reference intervals for adult Croatian Posavac horse. Vet. arhiv 89, 771-783, 2019.}

\section{ABSTRACT}

The aim of the study was to establish breed-specific hematological and biochemical reference intervals (RI) for Croatian Posavac horses. Strict criteria were established for inclusion of reference subjects, blood specimen collection and handling. Blood samples from 125 healthy, adult Croatian Posavac horses of both sexes (94 mares and 31 stallions) were used to determine RIs. Statistical analysis was performed according to the 2012 ASVCP guidelines for nonparametric RIs. RIs for hematological parameters from this study were quite compatible with RIs for warmblood horses for 11 out of the 20 measured parameters. The reported biochemical RIs in our study agree well with RIs for a mixed population of Croatian coldblood breeds, except for LDH, GGT and ALP. The RI for total protein and albumin differ substantially from the published RIs, and from a clinical viewpoint further investigation is warranted. The RIs established in this study provide a useful baseline for the clinical assessment of hematological and biochemical data of Croatian Posavac horses.

Key words: Croatian Posavac horse; hematological; biochemical; reference interval; breed specific

\section{Introduction}

Croatia has three indigenous coldblood horse breeds: the Croatian Posavac, the Croatian Coldblood and the Murinsulaner horse.

The Croatian Posavac is a unique breed, which developed over several hundred years out of the Slavonic-Posavina landrace crossed with Arabs, Lipizzans, Nonius and Thoroughbreds. Later Belgian, Ardennes, Percheron and Noriker coldblood stallions were used. In the past, the Posavac female breeding stock has contributed significantly to the creation of the Croatian coldblood. Historically, the Posavac horse was the most important Croatian horse. Professor D. Ubl, one of the founders of Croatian animal husbandry, first mentioned the breed under this name in 1885.

\footnotetext{
${ }^{*}$ Corresponding author:

Prof. Dr. Nada Kučer, Clinic for Internal Diseases, Faculty of Veterinary medicine, University of Zagreb, Heinzelova 55, 10000 Zagreb, Croatia, Phone: +385 12390 182; Fax: +385 12390 176; E-mail: nkucer@vef.hr
} 


\section{Grden et al.: Hematological and biochemical references for Croatian Posavac horse}

The Croatian Posavac is a typical middle-sized robust coldblood, with the temperament and some conformational features of a warmblood horse (PAPRIKA and IVANKOVIĆ, 2005). According to the Croatian agricultural agency's 2017 annual report, the Posavac is the second largest horse breed of of Croatia, in terms of numbers. In 2017 Croatia had a total of 23,209 horses, of which 13,418 were coldbloods and of these 4,871 belonged to the Croatian Posavac breed, which is $36.3 \%$ of all coldblood horses. In order to optimize the health of this breed, more specific physiological parameters must be collected and compared with other breeds. Among these are hematological and blood biochemical parameters.

Regarding interpretation of hematology and blood biochemistry results, GRÄSBECK et al., (1969) already introduced the concept of population-based reference values in human medicine in 1969. A decade later veterinary medicine followed suit (LUMSDEN et al. 1980; FRIENDSHIP et al. 1984).

Reference values are mostly reported as a reference interval (RI) within which 95\% of the reference individuals fall. Although commonly used in diagnostics, a universal method for their calculation is still being discussed in the clinical laboratory literature (FRIEDRICHS et al. 2012). Whatever the case, care should be taken in interpretation, because any reference interval (RI) including $95 \%$ of reference individuals still excludes $5 \%$ of healthy animals with values outside the reference intervals for the observed parameters.

The determination of population based reference intervals relies on the proper selection of healthy reference individuals. Procedures for verifying the health of the population should include at least a medical history and a physical examination. If possible, more proof of health could be included for the precision of the RI, such as data from a minimum database or the results of diagnostic imaging, ECG, fecal examination, endoscopy or any other diagnostic procedure deemed necessary to improve the reliability of the selection of truly healthy reference individuals (FRIEDRICHS et al., 2012). CYWIŃSKA et al. (2015) state that in any species breed-specific traits manifest as diversity in phenotypic appearance and disposition, which may also result in differences in blood composition, and this could be reflected in variations in hematological and biochemical variables.

Lately, many studies have shown variations in the reference values of various horse populations and breeds (ČEBULJ-KADUNC et al., 2002; ČEBULJ-KADUNC et al., 2003; LACERDA et al., 2006; PRITCHARD et al., 2009; MUNOZ et al., 2012; TAKASU et al., 2013; NIEDZWIEDZ et al., 2013; CYWINSKA et al., 2015; SAMPLE et al., 2015; AROS et al., 2017; PRVANOVIĆ BABIĆ et al., 2019), WRIGHT et al. (2019) recommended the use of the more appropriate individualized (subject-based) reference intervals for parameters with a high degree of variation between individuals. The underlying rationale of the current study is that RIs in laboratory medicine are critical for diagnostic accuracy. In humans there are marked inter- and intrapopulation variations in the reference ranges of laboratory parameters. This occurs even among populations of the same race, and is caused by environmental interaction, such as differences in pathogen exposure, nutrition and life at different altitudes (PATEL et al., 2007). The current study should provide a 


\section{Grden et al.: Hematological and biochemical references for Croatian Posavac horse}

basis for more appropriate individualized (subject-based) reference intervals for those parameters with a high degree of variation for individuals belonging to the Posavac coldblood breed. Similarly designed studies have already been reported for indigenous Croatian dog breeds (GRAČNER et al. 2007; ŽUBČIĆ et al. 2008; GRAČNER et al. 2011). Furthermore, PAĐEN et al. (2014) established hematological and biochemical RIs for a mixed population of subjects belonging to either the Croatian Posavac or Croatian Coldblood breeds. Also, PRVANOVIĆ BABIĆ et al. (2019) published reference values for hemogram and clinical biochemistry for the Murinsulaner horse. We found no papers published on specific hematological and biochemical reference intervals exclusively for the Croatian Posavac breed.

The objective of this study was to establish hematological and biochemical populationbased reference intervals (RI) for the Croatian Posavac horse. Due to its unique history and new breeding strategy in the past 15 years, genotype variation may have occurred recently and could have resulted in different RIs for certain blood parameters. The Croatian Posavac has a high cultural and genetic value, which justifies special attention for this breed.

\section{Materials and methods}

Animals, husbandry and nutrition. A total of 160 Croatian Posavac coldbloods were initially allocated for this study, 125 mares and 35 stallions, aged 1 to 25 years. The animals were randomly selected in the wider area of the town of Križ. The horses all were kept outside on pastures for most of the year. Along with grazing, they were fed corn once a week. Over the winter the horses were stabled and fed hay and small rations of corn or oats, and were given water twice daily.

Inclusion criteria. Animals were included in the study only if they had no history of disease in the previous thirty days prior to sampling, had been dewormed in previous 3 months, and were found healthy on clinical examination on the day of sampling. The routine clinical exam included inspection for gross clinical abnormalities, assessment of body condition, taking the rectal temperature, counting heart and respiratory rates, and auscultation of heart and lung sounds. Twenty-four horses failed the deworming criteria, and eleven horses were excluded from the study due to abnormal clinical findings. In total, 125 horses were included in the study, 94 mares and 31 stallions. As well as being healthy at the moment of sampling, all animals included remained healthy for at least 10 days after sampling. Blood sampling was done in early spring, at the end of the winter stabling period.

Sampling. Blood samples were collected from the jugular vein into vacuum tubes, with gel and cloth activator for biochemistry and K3-EDTA anticoagulant for hematology. Samples were kept in a refrigerator $\left(+4{ }^{\circ} \mathrm{C}\right)$ during transport to the laboratory. Hematology was performed within 8 hours of collection. Blood was allowed to clot in the serum tubes for a minimum of $30 \mathrm{~min}$ prior to centrifugation, then the samples were centrifuged at $1600 \mathrm{~g}$ for $10 \mathrm{~min}$ and kept frozen at $-20^{\circ} \mathrm{C}$ until analysis. 


\section{Grden et al.: Hematological and biochemical references for Croatian Posavac horse}

Hematology. Red blood cell count (RBC), hemoglobin concentration (HB), hematocrit (HCT), mean corpuscular volume (MCV), mean corpuscular hemoglobin $(\mathrm{MCH})$, mean corpuscular haemoglobin concentration $(\mathrm{MCHC})$, red blood cell volume distribution width (RDW), platelet count (PLT), mean platelet volume (MPV) and white blood cell count (WBC), were measured using an Animal Blood Counter (ABC), Horiba ABX Diagnostics, Montpellier, France. Differential blood cell count of neutrophils (NEU), lymphocytes (LYM), monocytes (MON), basophils (BAS) and eosinophils (EOS) was performed on a blood smear, stained with May-Grünwald Giemsa, using a light microscope at $\times 400$ magnification. The smears were further examined at $\times 1000$ magnification under oil immersion for the presence of Babesia caballi and Theileria equi.

Biochemistry. Total protein (TP), albumin (ALB), alkaline phosphatase (AP), aspartate aminotransferase (AST), lactate dehydrogenase (LDH), creatine kinase (CK), gamma-glutamyl transferase (GGT), total bilirubin (TBIL), blood urea nitrogen (BUN), creatinine (CREA), total cholesterol (CHOL), triglyceride (TRIG), total calcium (Ca), magnesium $(\mathrm{Mg})$, and phosphorus $(\mathrm{P})$ were determined in serum samples using an Olympus AU 600 biochemical analyzer.

Statistical analysis. Statistical analysis was preformed according to the 2012 ASVCP reference interval guidelines (FRIEDRICHS et al. 2012). MedCalc statistical software, version 18.11.3. was used. Data were first controlled for outliers and then RIs were calculated using non-parametric statistics, the $2.5^{\text {th }}$ and $97.5^{\text {th }}$ percentiles were used as the lower (LL) and upper reference limits (UL). Furthermore, ninety percent confidence intervals $(\mathrm{CI})$ around these two limits were determined.

The study protocol was approved by the Ethics Committee of the Veterinary Faculty, University of Zagreb, and confirmed at the 33rd Regular session of the Faculty Council on October $22^{\text {nd }} 2010$.

\section{Results}

From the initial 160 horses chosen for the study, a final number of 125 healthy individuals were selected and included in this study, which is $2.5 \%$ of the current Croatian Posavac population. Neither Babesiae nor Theileriae were detected in the blood smears. No outliers were found in the dataset. The results are presented in four tables. In the first two tables descriptive statistics and RIs with $90 \%$ CI for their LL and UL are given.

Table 1. Hematological reference intervals (RI) for Croatian Posavac, descriptive statistics and confidence interval of $90 \%$ for lower and upper limits

\begin{tabular}{|l|c|c|c|c|c|c|c|}
\hline & Mean & SD & Median & $\begin{array}{c}\text { Percentile } \\
2.5\end{array}$ & $\begin{array}{c}90 \% \text { CI of 2.5 } \\
\text { percentile }\end{array}$ & $\begin{array}{c}\text { Percentile } \\
97.5\end{array}$ & $\begin{array}{c}90 \% \text { CI of } \\
97.5 \\
\text { percentile }\end{array}$ \\
\hline $\mathrm{RBC}\left(\times 10^{6} / \mu \mathrm{L}\right)$ & 8.1 & 1.3 & 8.1 & 5.3 & $4.8-6.2$ & 11.8 & $10.6-12.5$ \\
\hline $\mathrm{HB}(\mathrm{g} / \mathrm{dL})$ & 12.17 & 2.02 & 12.0 & 8.45 & $7.7-9.2$ & 17.36 & $15.7-20.4$ \\
\hline $\mathrm{HCT}(\%)$ & 36.8 & 6.2 & 36.0 & 26.0 & $24.0-28.0$ & 55.6 & $46.0-62.0$ \\
\hline $\mathrm{MCV}(\mathrm{fL})$ & 45.9 & 5.00 & 46.0 & 37.0 & $37.0-38.0$ & 53.0 & $51.0-80.0$ \\
\hline
\end{tabular}


D. Grden et al.: Hematological and biochemical references for Croatian Posavac horse

Table 1. Hematological reference intervals (RI) for Croatian Posavac, descriptive statistics and confidence interval of $90 \%$ for lower and upper limits (continued)

\begin{tabular}{|l|c|c|c|c|c|c|c|}
\hline & Mean & SD & Median & $\begin{array}{c}\text { Percentile } \\
2.5\end{array}$ & $\begin{array}{c}90 \% \text { CI of 2.5 } \\
\text { percentile }\end{array}$ & $\begin{array}{c}\text { Percentile } \\
97.5\end{array}$ & $\begin{array}{c}90 \% \text { CI of } \\
97.5 \text { percentile }\end{array}$ \\
\hline MCH $(\mathrm{pg})$ & 15.0 & 1.3 & 15.0 & 12.0 & $12.0-13.0$ & 17.9 & $17.0-18.0$ \\
\hline MCHC $(\mathrm{g} / \mathrm{dL})$ & 32.96 & 0.89 & 33.0 & 31.25 & $29.5-31.8$ & 34.87 & $34.3-35.1$ \\
\hline RDW $(\%)$ & 16.7 & 0.7 & 17.0 & 15.0 & $14.0-16.0$ & 18.0 & $18.0-18.0$ \\
\hline PLT $\left(\times 10^{3}\right)$ & 257.0 & 85.6 & 243.0 & 100.7 & $83.0-139.0$ & 447.3 & $407.0-512.0$ \\
\hline MPV $(\mathrm{fL})$ & 5.9 & 0.5 & 6.0 & 5.0 & $5.0-5.0$ & 7.0 & $7.0-7.0$ \\
\hline WBC $\left(\times 10^{9} / \mathrm{L}\right)$ & 10.3 & 2.6 & 10.1 & 5.3 & $4.8-6.4$ & 14.9 & $14.3-15.7$ \\
\hline NEU \% & 47.2 & 11.6 & 48.0 & 25.0 & $24.00-28.0$ & 71.0 & $66.0-74.0$ \\
\hline NEU & 4.9 & 1.6 & 4.8 & 2.3 & $1.6-2.5$ & 9.0 & $8.14-10.0$ \\
\hline LYM \% & 49.8 & 11.88 & 49.0 & 27.0 & $21.0-29.0$ & 72.0 & $71.0-75.0$ \\
\hline LYM & 5.4 & 2.2 & 5.3 & 2.0 & $1.9-2.3$ & 11.1 & $9.7-11.7$ \\
\hline MON \% & 0.7 & 1.46 & 0.0 & 0.0 & $0.0-0.0$ & 5.0 & $4.0-9.0$ \\
\hline MON & 0.1 & 0.2 & 0.0 & 0.0 & $0.0-0.0$ & 0.5 & $0.4-0.9$ \\
\hline EOS \% & 1.9 & 2.9 & 0.0 & 0.0 & $0.0-0.0$ & 10.0 & $6.0-18.0$ \\
\hline EOS & 0.2 & 0.3 & 0.0 & 0.0 & 0.0 .0 .0 & 1.1 & $1.0-1.3$ \\
\hline BAS \% & 0.4 & 1.1 & 0.0 & 0.0 & $0.0-0.0$ & 3.0 & $2.0-9.0$ \\
\hline BAS & 0.1 & 0.1 & 0.0 & 0.0 & $0.0-0.0$ & 0.4 & $0.3-0.8$ \\
\hline
\end{tabular}

Table 2. Biochemical reference intervals (RI) for the Croatian Posavac breed, descriptive statistics and confidence interval of $90 \%$ for lower and upper limits of reference interval

\begin{tabular}{|l|c|c|c|c|c|c|c|}
\hline & Mean & SD & Median & $\begin{array}{c}\text { Percentile } \\
2,5\end{array}$ & $\begin{array}{c}90 \% \text { CI of 2.5 } \\
\text { percentile }\end{array}$ & $\begin{array}{c}\text { Percentile } \\
97.5\end{array}$ & $\begin{array}{c}90 \% \text { CI of } \\
97.5 \text { percentile }\end{array}$ \\
\hline ALP $(\mathrm{U} / \mathrm{L})$ & 237.4 & 93.1 & 221.0 & 82.5 & $70.0-111.0$ & 460.8 & $430.0-487.0$ \\
\hline AST $(\mathrm{U} / \mathrm{L})$ & 303.4 & 130.3 & 282.9 & 124.9 & $102.3-136.7$ & 715.2 & $521.70-783.7$ \\
\hline $\mathrm{CPK}(\mathrm{U} / \mathrm{L})$ & 219.5 & 107.0 & 212.0 & 80.2 & $13.0-89.0$ & 556.4 & $397.0-682.0$ \\
\hline $\mathrm{LDH}(\mathrm{U} / \mathrm{L})$ & 500.1 & 165.7 & 503.0 & 197.1 & $126.0-253.0$ & 858.4 & $757.0-895.0$ \\
\hline $\mathrm{GGT}(\mathrm{U} / \mathrm{L})$ & 14.3 & 8.1 & 12.4 & 2.4 & $1.5-5.0$ & 34.7 & $29.4-41.0$ \\
\hline $\mathrm{TBIL}(\mu \mathrm{mol} / \mathrm{L})$ & 19.9 & 8.5 & 18.0 & 9.2 & $5.9-10.5$ & 44.2 & $33.7-68.8$ \\
\hline $\mathrm{BUN}(\mathrm{mmol} / \mathrm{L})$ & 5.5 & 1.4 & 5.4 & 2.9 & $2.2-3.2$ & 8.7 & $7.7-9.8$ \\
\hline $\mathrm{CREA}(\mu \mathrm{mol} / \mathrm{L})$ & 132.3 & 25.7 & 131.0 & 82.3 & $81.0-90.0$ & 197.6 & $176.0-202.0$ \\
\hline $\mathrm{TP}(\mathrm{g} / \mathrm{L})$ & 79.8 & 8.6 & 80.0 & 60.8 & $58.8-65.2$ & 95.2 & $92.1-97.1$ \\
\hline $\mathrm{ALB}(\mathrm{g} / \mathrm{L})$ & 30.2 & 5.98 & 29.6 & 18.3 & $16.1-20.3$ & 41.3 & $39.6-43.3$ \\
\hline $\mathrm{CHOL}(\mathrm{mmol} / \mathrm{L})$ & 3.1 & 0.7 & 2.9 & 2.2 & $1.7-2.3$ & 4.6 & $4.5-4.8$ \\
\hline $\mathrm{TRIG}(\mathrm{mmol} / \mathrm{L})$ & 0.6 & 0.6 & 0.4 & 0.2 & $0.1-0.2$ & 3.0 & $1.7-4.0$ \\
\hline $\mathrm{Ca}(\mathrm{mmol} / \mathrm{L})$ & 3.3 & 0.3 & 3.3 & 2.6 & $2.4-2.8$ & 3.8 & $3.7-3.9$ \\
\hline $\mathrm{P}(\mathrm{mmol} / \mathrm{L})$ & 1.2 & 0.4 & 1.2 & 0.6 & $0.5-0.8$ & 2.0 & $1.9-2.4$ \\
\hline $\mathrm{Mg}(\mathrm{mmol} / \mathrm{L})$ & 0.8 & 0.1 & 0.8 & 0.6 & $0.3-0.7$ & 1.0 & $0.9-1.1$ \\
\hline
\end{tabular}


D. Grden et al.: Hematological and biochemical references for Croatian Posavac horse

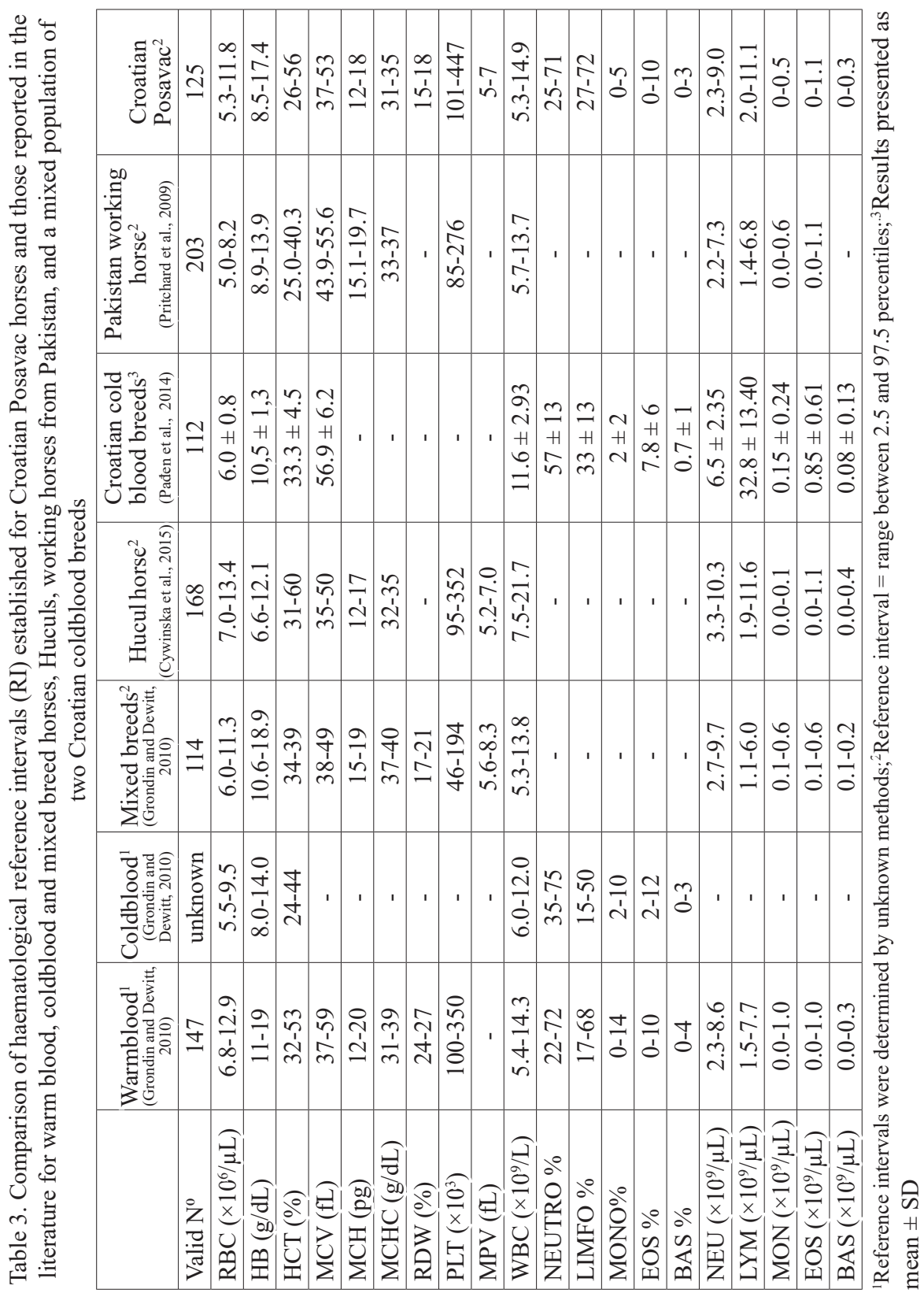


D. Grden et al.: Hematological and biochemical references for Croatian Posavac horse

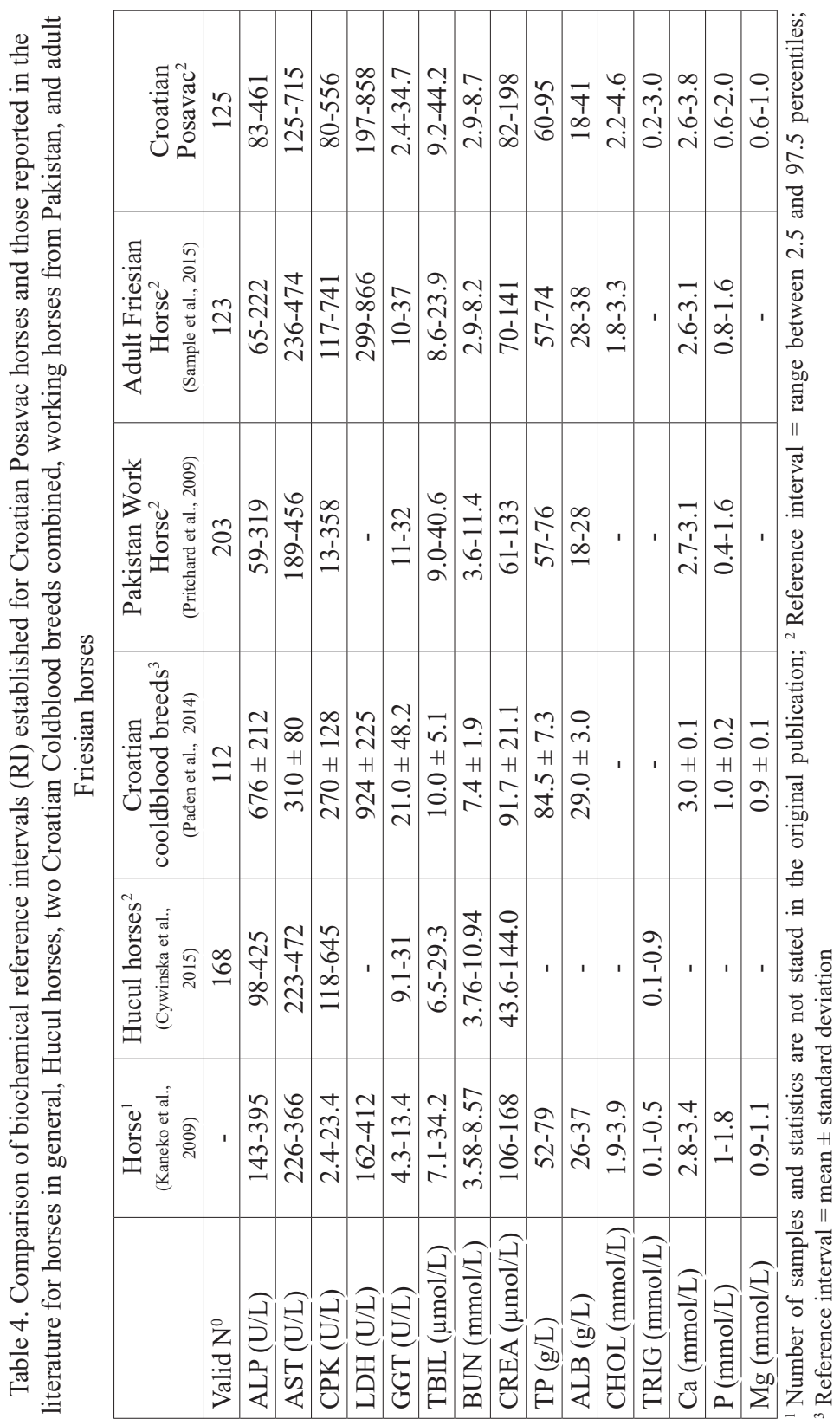

Vet. arhiv 89 (6), 771-783, 2019 
D. Grden et al.: Hematological and biochemical references for Croatian Posavac horse

\section{Discussion}

This is the first study on RIs for hematology and blood biochemistry in healthy adult Croatian Posavac horses. This reference population comprised $2.5 \%$ of the adult population, which seems an acceptable sample size.

Comparison of the published RIs (ČEBULJ-KADUNC et al. 2002; ČEBULJKADUNC et al. 2003; LACERDA et al. 2006; PRITCHARD et al. 2009; MUNOZ et al. 2012; TAKASU et al. 2013; NIEDZWIEDZ et al. 2013; CYWINSKA et al. 2015; SAMPLE et al. 2015; AROS et al. 2017; PRVANOVIĆ BABIĆ et al. 2019) was demanding due to non-standardized terminology, methodology and statistical methods used (HENNY et al., 2016). Some studies present their RIs according to the 2012 ASVCP reference interval guidelines, however, others still report their results as mean \pm 2 standard deviations, often without reporting the statistical distribution function of their parameters. Even more problematic for comparison were those studies that only gave the RI without any further specification.

The 125 horses in our study compared well with the numbers used in the studies by LACERDA et al. (2006), PAĐEN et al. (2014) and SAMPLE et al. (2015). PAĐEN et al. (2014) only sampled $1 \%$ of a mixed population of cold bloods. These samples were collected in June and July of the 1999 and 2001, clearly later in the year than our samples.

The RI for red blood cell counts in the present study is similar to that found by GRONDIN and DEWITT (2010) for mixed breeds. Data by PAĐEN et al. (2014) however, they could not be compared directly. Nevertheless, the estimated LL for RBC appeared lower and the RI range was smaller than in our purebred population. Also the LL for HCT appears lower. Furthermore, for the MCV the UL tended to be the highest among the listed studies. The secondary RBC indices in our study were most compatible with the RI for warmblood breeds.

The white blood cell RI for our Posavac population is compatible with the RIs for warmblood horses and mixed breed populations, while in one coldblood population a lower UL was present (GRONDIN and DEWITT, 2010). ULs for leukocyte numbers vary from $14 \times 10^{9} / \mathrm{L}$ to $15 \times 10^{9} / \mathrm{L}$ (GRONDIN and DEWITT, 2010). CYWIŃSKA et al. (2015), however, report a wider WBC range in Hucul horses with UL of $21.7 \times 10^{9} / \mathrm{L}$. This was explained as a consequence of stress and age. Indeed, a stress leukogram is known to be caused by acute stress-induced recruitment of the marginal leukocyte population.

For differential WBC counts, we reported values generally compatible with the rest of the RIs reported by GRONDIN and DEWITT (2010), CYWINSKA et al. (2015), PRTCHARD et al. (2009). PAĐEN et al. (2014) report a wider RI for eosinophils due to the higher UL than others. This trend towards eosinophilia was likely caused by continuous exposure to parasites due to an environmental challenge, according to the authors (PAĐEN et al., 2014). Since population based reference intervals rely on the 


\section{Grden et al.: Hematological and biochemical references for Croatian Posavac horse}

proper selection of healthy reference individuals, the current study only included horses adequately treated against endoparasites.

The platelet number in our study had the largest RI, caused by a slightly higher UL than others reported in Table 3.

Generally, the RI values for the hematology parameters of our study were most compatible with the RI for warmblood horses in Table 3, in 11 out of 20 parameters measured, which is surprising considering that the Posavac is a coldblooded horse, although some warmblood traits are still present. The Posavac horse and the Croatian Coldblood are closely related populations (IVANKOVIĆ et al. (2009). There is strong evidence that Posavac horse, although slightly smaller, is a variant of the Croatian Coldblood and is not a distinct breed (GALOV et al., 2013). Possibly the consequence of the recent split of the breeds into 2 separate closed studbook governed populations, has not been long enough for specific genetic signatures. Apparently, no major changes in red and white blood cell parameters have occurred.

Regarding the RI for biochemical parameters, the RI for ALP in our study agrees with that reported by CYWIŃSKA et al. (2015), whereas those for LDH and GGT correspond with data by SAMPLE et al. (2015).

The RI for total protein (TP) and albumin (ALB) in the Croatian Posavac is larger than the RIs for TP and ALB reported by KANEKO et al. (2009), PRITCHARD et al. (2009), SAMPLE et al. (2015) and CYWINSKA et al. (2015). Only PAĐEN et al. (2014) similarly report a large RI. GULL et al. (2007) report an even higher TP of $86.3 \pm 9.5$ $(\mathrm{g} / \mathrm{L})$, in apparently healthy horses. We believe our results are due to the horses' diurnal access to water, which is part of the traditional husbandry practice. Horses drink most water within an hour of feeding (SCHOTT, 2018), and the sampling in our study was done during the morning feed, so that a mild hemoconcentration could have been present, which also explains the slightly higher HCT values.

The remaining RIs reported in our study agree best with the RIs reported by PAĐEN et al. (2014), however the RIs for ALP, LDH and GGT differed substantially. PAĐEN et al. (2014) explained the higher values of LDH as breed characteristics, partially due to exposure to high intensity exercise. In this respect, we think that LDH activity should be seen in combination with CK activities. The higher CK RI reported by PAĐEN et al. (2014) was interpreted as a consequence of the outdoor living conditions of their sampled population. These authors state that being at pasture causes more intense muscle activity and potential muscle damage would occur. It is possible to challenge this notion in a healthy population, however, in principle muscle damage at pasture may be associated with vitamin E/Se deficiency or with hypoglycin associated atypical myopathy. The authors did not report any indications that these risk factors had been present. Moreover, it is not logical to qualify the usual activities of horses at pasture as heavy muscle damaging 
exercise. On the other hand, the possible influence of some popular Belgian and French coldblood stallions, used in the late 19th and early 20th century, may have caused the spread of the GYS1 H-allele, which is responsible for Polysaccharide Storage Myopathy (PSSM). It is possible that PAĐEN et al. (2014) unintentionally sampled some animals that had suffered from mild PSSM shortly prior to sampling. Further studies should be performed to determine the frequency of the H-allele of GYS1 in the Croatian Coldblood and Posavac populations.

PAĐEN et al. (2014) stipulate that the higher values of ALP and the increased eosinophil count, reported in their study, are due to increases in the intestinal ALP isozyme, which is associated with parasitic damage of epithelial cells (PAĐEN et al. 2014). This idea is further corroborated by the presence of eosinophilia. Alongside the eosinophilia and the trend towards higher ALP activities, the wider RIs for GGT and CK cast some doubt on the health of some of the selected reference individuals in PAĐEN et al. (2014).

The RIs for TP and ALB in our study are substantially different from other RIs, apart from those of PAĐEN et al. (2014). From a clinical viewpoint, a correct interpretation of TP and ALB results may be difficult. Therefore, further investigation is warranted.

The reliability of study results depends strongly on pre-analytical as well as analytical errors. In this study every effort was made to avoid or at least minimize these. The construction of separate RIs for animals of different ages and genders could not be achieved in our research because the total study included 125 samples, making proper stratification by age and gender impossible due to the small numbers per stratus.

We are confident that this study has generated a reliable set of RIs for the adult Croatian Posavac horse, enabling correct interpretation of laboratory results of Croatian Posavac horses. Future studies with larger samples may provide useful information on the influence of age and gender. Whether these are clinically relevant, remains to be seen.

\section{References}

AROS, K., J. CARRASCO, R. BRIONES, T. A. TADICH (2017): Haematological and serum biochemical reference values for urban-working equines in Chile. Austral. J. Vet. Sci. 1, 27-33.

CYWIŃSKA, A., M. CZOPOWICZ, L. WITKOWSKI, R. GÓRECKA, A. DEGÓRSKI, M. GUZERA, P. SZCZUBEŁEK, A. TURŁO, A. SCHOLLENBERGER, A. WINNICKA (2015): Reference intervals for selected hematological and biochemical variables in Hucul horses. Pol. J. Vet. Sci. 18, 439-445.

DOI: $10.1515 /$ pjvs-2015-0056

ČEBULJ-KADUNC, N., M. BOŽIĆ, M. KOSEC, V. CESTNIK (2002): The influence of age and gender on haematological parameters in lipizzan horses. J. Vet. Med. A 49, 217-221. 
D. Grden et al.: Hematological and biochemical references for Croatian Posavac horse

ČEBULJ-KADUNC, N., M. KOSEC, V. CESTNIK (2003): The Variations of White Blood Cell Count in Lipizzan Horses. J. Vet. Med. A 50, 251-253.

FRIEDRICHS, K. R., K. E. HARR, K. P. FREEMAN, B. SZLADOVITS, R. M. WALTON, K. F. BARNHART, J. BLANCO-CHAVEZ (2012): ASVCP reference interval guidelines: determination of de novo reference intervals in veterinary species and other related topics. Vet. Clin. Pathol. 41, 441-453.

DOI: $10.1111 / \mathrm{vcp} .12006$

FRIENDSHIP, R. M., J. H.LUMSDEN, I. MCMILLAN, M. R. WILSON (1984): Hematology and biochemistry reference values for Ontario Swine. Can. J. Comp. Med. 48, 390-393.

GALOV, A., K. BYRNE, T. GOMERCIC, M. DURAS, H. ARBANASIC, M. SINDICIC, D. MIHELIC, A. KOVACIC, S.M.FUNK (2013): Genetic structure and admixture between the Posavina and Croatian Coldblood in contrast to Lipizzan horse from Croatia. Czech J. Anim. Sci. 58, 71-78.

DOI: $10.17221 / 6617-C J A S$

GRAČNER, D., LJ. BEDRICA, Č. LABURA, D. MATIČIĆ, G. GREGURIĆ GRAČNER, M. SAMARDŽIJA (2007): Blood groups and haematology in Istrian pointers. Vet. arhiv 77, 95-102.

GRAČNER, D., LJ. BEDRICA, D. POTOČNJAK, D. SAKAR, M. SAMARDŽIJA, H. CAPAK, G. GREGURIĆ GRAČNER (2011): Blood groups and haematology indicators in Croatian indigenous breeds of dog. II Dalmatian dog. Vet. arhiv 81, 111-117.

GRASBECK, R., N. E. SARIS (1969): Establishment and use of normal values. Scand. J. Clin. Lab. Invest. 26, S62-S63.

GRONDIN, T. M., S. F. DEWITT (2010): Normal hematology of the horse and donkey. In: Shalm's Veterinary Hematology. $6^{\text {th }}$ ed. (Weiss, D. J., K. J. Wardrop, Eds.), Wiley-Blackwell Ames, Iowa, USA, pp. 821-828.

GUL, S. T., M. AHMAD, A. KHAN, I. HUSSAIN (2007): Haemato-biochemical observations in apparently healthy equine species. Pakistan Vet. J. 27, 155-158.

HENNY, J., A. VASSAULT, G. BOURSIER, I. VUKASOVIC, P. MESKO BRGULJAN, M. LOHMANDER, I. GHITA, F. A. ANDREU, C. KROUPIS, L. SPRONGL, M. H. THELEN, F. J. VANSTAPEL, T. VODNIK, W. HUISMAN, M. VAUBOURDOLLE (2017): Recommendation for the review of biological reference intervals in medical laboratories. Clin. Chem. Lab. Med. 54, 1893-1900.

DOI: 10.1515/cclm-2016-0793_C

IVANKOVIĆ, A., J., RAMLJAK, P. DOVČ, N. KELAVA, M. KONJAČIĆ (2009): Genetic structure of three Croatian horse breeds: implications for their conservation strategy. Ital $\mathrm{J}$ Anim Sci 8, 677-689.

KANEKO, J. J., J. W. HARVEY, M. L. BRUSS (2009): Clinical Biochemistry of Domestic Animals. Appendix VIII. Blood Analyte Reference Values in Large Animals. $6^{\text {th }}$ ed., Academic Press Elsevier, Amsterdam, Boston Heidelberg, London, New York, Oxford, Paris, San Diego, San Francisco, Singapore, Sydney, Tokyo, pp. 882-888.

Vet. arhiv 89 (6), 771-783, 2019 
D. Grden et al.: Hematological and biochemical references for Croatian Posavac horse

LACERDA, L., R. CAMPOS, M. SPERB, E. SOARES, P. BARBOSA, E. GODINHO, R. FERREIRA, V. SANTOS, F.D. GONZÁLEZ (2006): Hematologic and biochemical parameters in three high performance horse breeds from southern Brazil. Arch. Vet. Sci. 11, 40-44.

DOI: $10.5380 /$ avs.v11i2.6783

LUMSDEN J. H., R. ROWE, K. MULLEN (1980): Hematology and biochemistry reference values for the light horse. Can. J. Comp. Med. 44, 32-42.

MUÑOZ, A., C. RIBER, P. TRIGO, F. CASTEJÓN (2012): Age and gender related variations in hematology, clinical biochemistry. Res. Vet. Sci. 93, 943-949.

DOI: 10.1016/j.rvsc.2011.11.009

NIEDZWIEDZ, A., Z. JAWORSKI, H. FILIPOWSKI, M. ZAWADZKI, M. WRZOSEK, M. SŁUZEWSKA-NIEDZWIEDZ, J. NICPON (2013): Serum biochemical reference intervals for the Polish Konik horse (Equus cabalus gmelini Ant.). Vet. Clin. Pathol. 42, 66-69.

DOI: $10.1111 /$ vcp. 12020

PAĐEN L., T. GOMERČIĆ, M. ĐURAS, H. ARBANASIĆ, A. GALOV (2014): Hematological and serum biochemical reference values for the posavina and croatian coldblood horse breeds. Acta Vet-Beograd 64, 200-212.

DOI: $10.2478 /$ acve-2014-0019

PAPRIKA, S., A. IVANKOVIĆ (2005): Exterior features of the Posavina horse from the area of the Odra and Lonja field. Stočarstvo 59, 91-119 (in Croatian).

PATEL, K. V., T. B. HARRIS, M. FAULHABER, S. B. ANGLEMAN, S. CONNELLY, D. C. BAUER, L. H. KULLER, A. B. NEWMAN, J. M. GURALNIK (2007): Racial variation in the relationship of anemia with mortality and mobility disability among older adults. Blood 109, 4663-4670.

DOI: $10.1182 /$ blood-2006-10-055384

PRITCHARD, J. C., C. C. BURN, R. S. ALISTAIR, A. BARR, R. HELEN, A. WHAY (2009): Haematological and serum biochemical reference values for apparently healthy working horses in Pakistan. Res. Vet. Sci. 87, 389-395.

DOI: 10.1016/j.rvsc.2009.05.003

PRVANOVIĆ BABIĆ, N., A. KOSTELIĆ, B. NOVAK, D. ŠALAMON, B. TARIBA, N. MAĆEŠIĆ, T. KARADJOLE, G. BAČIĆ, LJ. BEDRICA (2019): Reference values and influence of sex and age on hemogram and clinical biochemistry in protected and endangered Murinsulaner horses. Vet. arhiv 89, 25-42.

DOI: $10.24099 /$ vet.arhiv.0479

SAMPLE, S. H., K. M. FOX, D. WUNN, E. ROTH, K. R. FRIEDRICHS (2015): Hematologic and biochemical reference intervals for adult Friesian horses from North America. Vet. Clin. Pathol. 44, 194-199.

DOI: $10.1111 /$ vcp. 12248 
D. Grden et al.: Hematological and biochemical references for Croatian Posavac horse

SCHOTT, H. C. $2^{\text {nd }}$ (2018): Examination of the urinary system. In: Equine Internal Medicine. $4^{\text {th }}$ ed. (Reed, S. M., M. B. Warwick, D. C. Sellon, Eds.) Saunders Elsevier, St. Louis, pp. 909-923.

TAKASU, M., N. NAGATANI, T. TOZAKI, H. KAKOI, M. MAEDA, T. MURASE, H. MUKOYAMA (2013): Hematological and biochemical reference values for the endangered kiso horse. J. Equine Sci. 24, 75-78.

DOI: $10.1294 /$ jes. 24.75

WRIGHT, M. E., E. L. CROSER, S. RAIDAL, R. M. BARAL, W. ROBINSON, J. LIEVAART, K. P. FREEMAN (2019): Biological variation of routine haematology and biochemistry measurands in the horse. Equine Vet. J. 51, 384-390.

DOI: $10.1111 /$ evj.13017

ŽUBČIĆ, D., LJ. BEDRICA, D. GRAČNER, I. HARAPIN, M. FURY, J. JEREMIĆ (2008): Blood groups, haematology and clinicochemical indicators in indigenous breeds of dog. I. Croatian sheepdog. Vet. arhiv 78, 141-147.

Received: 6 June 2019

Accepted: 16 September 2019

\section{GRDEN, D., J. GOTIĆ, K. ŠIMONJI, N. KUČER, V. MRLJAK, I. ŠMIT, M. CRNOGAJ, V. MATIJATKO: Referentni intervali za hematološke i biokemijske parametre u odraslog hrvatskog posavca. Vet. arhiv 89, 771-783, 2019.}

\section{SAŽETAK}

Svrha ovoga istraživanja bila je utvrditi referentne intervale za hematološke i biokemijske parametre u konja pasmine hrvatski posavac. Postavljeni su strogi kriteriji odabira konja za istraživanje te sakupljanja i postupka s uzorcima krvi. Uzorci krvi od 125 zdravih odraslih posavaca oba spola (94 kobile i 31 pastuha) korišteni su za određivanje referentnih intervala. Statistička analiza učinjena je u skladu s preporukom ASVCP-a iz 2012. za neparametrijske referentne intervale. Dobivene vrijednosti referentnih intervala za biokemijske parametre iz našega istraživanja u skladu su s referentnim intervalima objavljenim za dvije hrvatske hladnokrvne pasmine zajedno, osim za LDH, GGT i ALP. Referentni interval za ukupne proteine i albumine u našem istraživanju u velikoj mjeri odstupa od dosad objavljenih referentnih intervala i smatramo da je potrebno provesti dodatna istraživanja. Referentni intervali utvrđeni u ovom istraživanju korisna su osnova u kliničkoj interpretaciji nalaza hematoloških i biokemijskih pretraga u hrvatskog posavca.

Ključne riječi: hrvatski posavac; hematologija; biokemija; referentni interval; pasminska svojstva 
